Article

\title{
Can Glyphosate-Based Herbicides Contribute to Sustainable Agriculture?
}

\author{
Sheldon Krimsky
}

check for

updates

Citation: Krimsky, S. Can

Glyphosate-Based Herbicides Contribute to Sustainable

Agriculture? Sustainability 2021, 13,

2337. https://doi.org/10.3390/

su13042337

Academic Editor: Roberto Mancinelli

Received: 15 January 2021

Accepted: 16 February 2021

Published: 21 February 2021

Publisher's Note: MDPI stays neutral with regard to jurisdictional claims in published maps and institutional affiliations.

Copyright: (C) 2021 by the author. Licensee MDPI, Basel, Switzerland. This article is an open access article distributed under the terms and conditions of the Creative Commons Attribution (CC BY) license (https:// creativecommons.org/licenses/by/ $4.0 /)$.
Department of Urban, Environmental Policy and Planning, School of Arts and Sciences, Tufts University, Medford, MA 02155, USA; sheldon.krimsky@tufts.edu

\begin{abstract}
Glyphosate-based herbicides (GBHs) have become the leading agricultural herbicides used globally since the development of genetically engineered herbicide-tolerant crops. This paper investigates whether GBHs are consistent with or supportive of sustainable agriculture. Agricultural sustainability is defined by generally agreed upon goals: (1) promoting agroecology; (2) protecting soils and the Earth's natural resources; (3) protecting biodiversity; and (4) enhancing the quality of life and health of farmers, farm workers, and society. Through an in-depth examination of the scholarly literature, the paper explores whether the scientific studies of GBHs are consistent with their sustainable applications in agriculture in the areas of human health, non-tillage agriculture, soil quality, aquatic ecosystems and beneficial, non-target species. Based on the four generally agreed upon goals listed above for agricultural sustainability, the paper finds that GBHs are not consistent with sustainability goals.
\end{abstract}

Keywords: glyphosate; sustainable agriculture; Roundup; weed resistance; POEA

\section{Introduction}

The beginnings of agriculture can be traced to the Middle East, most likely in the Fertile Crescent, around 10,000-12,000 years ago [1]. Up until that time humans were hunter gatherers, moving when required to find new food sources. Over centuries farmers used a multitude of methods to protect crops from insects and weeds. The latter were pulled out by hand until the development of chemical herbicides.

Sustainable agriculture was introduced as a concept in 1987 in the United Nations' report titled Our Common Future (also called the Brundtland Report, named after the chairperson of the commission), issued by the World Commission on Environment and Development [2].

The application of biotechnology to produce crops was introduced in the mid-1990s [3]. Agriculture began to transition from traditional breeding, which included genetic selection, exposure of plant cells to radiation and mutagenic chemicals, and hybridization, to molecular breeding, which involves genetic modification through recombinant DNA techniques or genetic editing with CRISPR (clustered regularly interspaced short palindromic repeats).

The introduction of genetically engineered seeds, beginning with insect resistant and herbicide tolerant crops, brought international opposition. In response, the European community established a regulatory system that involved risk analysis, testing programs, and very restricted adoption of GMOs. In contrast, the United States did not require testing but began with the assumption of "substantial equivalence": that GMOs were substantially or essentially equivalent to crops produced through traditional breeding methods [4]. The methods used to produce the crops, i.e., recombinant DNA techniques or, subsequently, CRISPR, were not factors in crop risk assessment.

As new biotechnology products entered the agricultural sector, the interest in sustainability grew globally, activated by an awareness of climate change, the pollution of the oceans and the loss of biodiversity, the decline in soil quality, and the rise in agrochemical 
pollution. The United States and Brazil became leaders in the large-scale agriculture utilization of genetically engineered crops (also known as GMOs). Most of the staple crops in these countries, including corn and soybeans, were GMO products. It should be recognized that glyphosate is used functionally with GMOs to maintain a monocultural crop system.

With such large sectors of the agricultural economy dedicated to GMO crops, the question of whether GMOs were or could be compatible with sustainable agriculture began to gain serious attention. Some agricultural experts have asserted that new plant breeding technologies (molecular breeding) offer considerable potential for sustainable agriculture and food security. Qain wrote that GMOs can increase yields, increase crop diversity, and create crops with better resistance to pests and diseases, with more resilience to climate change and improved nutritional quality [5]. Others have reached a contrary conclusion. Allison Wilson in her book chapter, "Will gene-edited and other GM crops fail sustainable food systems?", argues that molecular breeding produces unintentional traits in commercial GM crops, which results in their failure to meet sustainable agriculture criteria [6]. One subset of GMOs, such as corn and soybeans, were designed to be used with glyphosate-based herbicides [7]. This paper will explore the question of whether this class of herbicides can contribute positively to sustainable agriculture.

Since glyphosate-based herbicides represent one component of a system of agriculture based on the molecular breeding of crops, methodologically, one cannot prove that a component is sustainable without taking into consideration the entire system. However, if it can be shown that a component of the agricultural system is unsustainable, that is, it violates the conditions of sustainability, then it can be argued that the agricultural system is unsustainable. The paper begins by outlining the core principles of sustainable agriculture and then discusses whether glyphosate-based herbicides (GBHs) meet these standards.

\section{What Is Meant by "Sustainable Agriculture"?}

In Our Common Future, the World Commission on Environment and Development report (1987), also called the Brundtland Report, it is stated that [8]:

"rapid growth combined with deteriorating income distribution may be worse than slower growth combined with redistribution in favour of the poor. For instance, in many developing countries the introduction of large-scale commercial agriculture may produce revenue rapidly but may also dispossess many small farmers and make income distribution more inequitable. In the long run, such a path may not be sustainable; it impoverishes many people and can increase pressures on the natural resource base through over commercialized agriculture and through the marginalization of subsistence farmers. Relying more on smallholder cultivation may be slower at first, but more easily sustained over the long term."

The concepts that underscore sustainability are protecting the Earth's natural resources for future generations, equitable income distribution from the production of food, and promoting smallholder cultivation. According to the report, the challenge of sustainable agriculture is to raise not just average productivity and incomes, but also the productivity and incomes of those poor in resources. Food security is not just a question of raising food production, but of ensuring that the rural and urban poor do not go hungry during the short-term or amidst a local food scarcity. All this requires the systematic promotion of equity in food production and distribution. Elsewhere the report notes: "Land use in agriculture and forestry must be based on a scientific assessment of land capacity, and the annual depletion of topsoil, fish stock, or forest resources must not exceed the rate of regeneration." Regenerative agriculture is the operative term.

E. Lichtfouse et al. wrote: "While conventional agriculture is driven almost solely by productivity and profit, sustainable agriculture integrates biological, chemical, physical, ecological, economic, and social sciences in a comprehensive way to develop new farming practices that are safe and do not degrade our environment" [9].

The National Academies' book "Toward Sustainable Agricultural Systems in the 21st Century" [10] proposes as a definition of sustainable agriculture: Improving sustainabil- 
ity is a process that moves farming systems along a trajectory toward meeting various socially determined sustainability goals as opposed to achieving any particular end-state. Agricultural sustainability is defined by four generally agreed upon goals:

- To satisfy human food, feed, and fiber needs, and contribute to biofuel needs.

- To enhance environmental quality and the resource base.

- To sustain the economic viability of agriculture.

- To enhance the quality of life of farmers, farm workers, and society as a whole.

From these convergent viewpoints on sustainable agriculture, we use as guiding points: promoting agroecology, protecting the resource base of natural systems for future generations including and especially the soil, protecting biodiversity, and enhancing the quality of life and health of farmers, farm workers, and society as a whole. Buechs discusses the importance of indicators for biodiversity and sustainable agricultural systems [11]. Applying these concepts as our criteria, we can now investigate the scientific literature on the herbicide glyphosate and its many formulations to see if agriculture that is based on this herbicide fulfills these sustainability goals. Our first review will be on the safety of glyphosate to farmers, farm workers, and society.

\section{Glyphosate and Human Safety}

Henri Martin was a Swiss chemist working for a pharmaceutical company in 1950 when he discovered a synthetic compound called glyphosate, a derivative of the amino acid glycine. The compound was not found to have therapeutic value.

In 1970, Monsanto scientists were reviewing chemicals for water softening applications. Quite by accident they found several synthesized compounds related to glyphosate that exhibited herbicidal properties. With Monsanto's entry into the agricultural biotechnology sector, these compounds had some potential value. Soon thereafter, Monsanto patented a formulation of glyphosate under the trade name Roundup. It received its first approval from the Environmental Protection Agency (EPA) as a broad-spectrum herbicide in 1974. The EPA classified the active ingredient in Roundup, notably glyphosate, in 1985 as a possible human carcinogen based on rodent studies. Roundup was re-registered by EPA in 1993, whereupon the agency found "it does not impose unreasonable risks or adverse effects to humans or the environment." EPA's assessment was based heavily on unpublished industry-funded studies [12,13]. Roundup went off patent in 2000 resulting in different formulations, some with higher concentrations of glyphosate [14].

The International Agency for Research on Cancer (IARC) of the World Health Organization issues periodic reports on potential chemical carcinogens. In 2017, as part of its review of a number of chemicals, the IARC reported its finding that glyphosate was a "probable human carcinogen", specifically citing non-Hodgkin lymphoma (NHL). The IARC's finding that glyphosate was a probable human carcinogen was based on peer reviewed published studies [15]. Since the IARC's report was issued, juries have ruled in favor of plaintiffs who have claimed that glyphosate has caused their cancer. Some subsequent studies have disputed the claim. In 2020, Denato et al. undertook a meta-analysis of epidemiological studies on the association between occupational exposure to glyphosate and cancer. They reported "no overall evidence of an increased risk for both NHL and multiple myeloma [16]." Williams et al. concluded that glyphosate is unlikely to pose a carcinogenic risk to humans [17].

Based on the IARC report and multiple jury decisions, glyphosate fails to meet one factor for sustainable agriculture: its unproven safety for farmers and applicators. Neither the IARC nor the EPA cite any definitive human studies on glyphosate toxicology. The IARC based its "probable carcinogen" designation largely on animal studies. Many studies on humans, their cells or semen, revealed suggestive evidence of adverse health effects of glyphosate-formulated herbicides.

Many other studies point to possible human effects of glyphosate, which, while not definitive, do paint a picture of an agricultural chemical that does not support sustainability criteria [18]. Some studies have found residues of glyphosate in food and drinking water, 
with consumers being exposed to higher levels from many different sources. The effects of these exposures are currently not known but raise additional questions about the safety of the herbicide to humans [19]. A consensus statement of 14 scientists concluded that the regulatory estimates of tolerable daily intakes for glyphosate in the European Union and the United States is based on outdated science and that preliminary data suggest that old assumptions about glyphosate safety are now in question. They reported: "A thorough and modern assessment of GBH (glyphosate-based herbicide) toxicity will encompass potential endocrine disruption, impacts on the gut microbiome, carcinogenicity, and multigenerational effects" [20].

Munoz et al. (2020) studied glyphosate as a possible endocrine-disrupting chemical (EDC) and concluded that glyphosate "satisfies at least 8 KCs (key characteristics) of an EDC but noted that "prospective cohort studies are still needed to elucidate the real effects on the human endocrine system" [21].

The IARC based its "probable human carcinogen" designation largely on animal studies. Several human studies have revealed suggestive evidence of adverse health effects of GBHs, including a meta-analysis supporting the linkage between GBH and non-Hodgkin lymphoma [22]. Parvez et al. (2018) undertook the first study of glyphosate exposure of pregnant women in the United States. Their study provided direct evidence of maternal glyphosate exposure and its correlation with shortened pregnancy. Moreover, they found quantifiable levels of glyphosate in over $90 \%$ of the pregnant women they tested [23]. Another study examined the sperm of healthy men, which investigators exposed to small quantities of Roundup. Their results indicated that the direct exposure of semen samples to Roundup at relatively low concentrations had adverse effects on sperm motility [24].

Woźniak et al. (2018) studied the effect of Roundup and glyphosate on human peripheral blood mononuclear cells (PBMCs). They found that Roundup, at low concentrations, caused much greater damage to DNA (genotoxicity) than glyphosate by itself [25]. Hao et al. (2020) demonstrated that Roundup damages human lung cells and constitutes a potential human health risk [26]. Hao et al. (2019) reported that Roundup induces DNA damage and cell death in human cells [27]. Additionally, Defarge et al. (2026) showed that glyphosate-based herbicides had endocrine effects on human cells [28].

In a systematic review of the literature on the effects of glyphosate exposure on human health in both epidemiological and in vitro studies, Agostini et al. (2019) found "the deleterious effects of GLY (glyphosate) exposure on human health were observed in epidemiological studies ... however, most of these studies have not determined the GLY dosage to confirm a direct effect. While GLY toxicity is clear in human cells, epidemiological studies investigating individuals exposed to different levels of GLY have reported contradictory data. Therefore, based on the current available in vitro and epidemiological data, it is not possible to confirm the complete safety of GLY use" [29].

Hurtado et al. (2020) studied the effects of aerial spraying of glyphosate on sugar crops in a region of Columbia. They found that mass spraying, while increasing productivity for the sugar growers, resulted in the "toxic dispossession" of ethnic communities in the region [30]. People left the area because of the adverse health effects they experienced from the sprayed crops.

In summary, the epidemiological studies show mixed results on whether glyphosatebased herbicides are hazardous to humans, while in vitro studies show extensive evidence that GBHs are toxic to human cells.

\section{Animal Studies of GBHs}

Animal studies (see Table 1) have shown a diverse range of adverse impacts for glyphosate-based herbicides. For example, Owagboriaye et al. (2017) found that one formulation of glyphosate has been found to be an endocrine disruptor in animal studies [31].

"Our study has shown that Roundup has the capacity to induce reproductive toxicity in the male reproductive system of the exposed animal. It is also a potent endocrine disruptor. We can conclude that the disruption in the normal testicular 
cellular architecture observed in the rats exposed to Roundup in this study, which could probably lead to abnormal hormonal secretion and abnormal sperm properties. may be attributed to the oxidative stress inflicted on the gonad of the exposed rats by the active ingredient in Roundup. This assumes significance and a public health concern considering increasing use of Roundup and presence of its residues in food and drinking water, thereby, increasing possible routes of exposure in humans."

Another rodent study by Lozano et al. (2018) revealed an adverse effect of Roundup on rat gut microbiome [32]. Pandey et al. (2015) reported on Roundup's disruption of the adrenal gland of male rats [33]. Additionally, Kubsad et al. (2019) studied pregnant female rats exposed to glyphosate during 8-14 days of gestation. They found that glyphosate induced epigenetic transgenerational effects and wrote that "glyphosate was found to promote the epigenetic transgenerational inheritance of disease and pathology through germline" [34]. Negligible effects were observed on the gestating mother and her offspring, but a significant increase in pathology and disease were found in the 2nd and 3rd generation rats. Other studies on rodents and rabbits showing adverse effects from Roundup or other GBHs are given in Table 1.

Table 1. Glyphosate-Based Herbicides: Effects on rodents, rabbits, aquatic species, beneficial insects and non-target species, and soil. A sample of the literature.

\begin{tabular}{|c|c|c|}
\hline A. Rodents \& Rabbits & Toxic Effects & Sources Reporting Effects \\
\hline Rabbit Semen & Toxic effects & Cai et al., 2017 [35] \\
\hline Rat uterus & Disrupts uterine development & Schimpf et al., 2016 [36] \\
\hline Rat Brain & Toxic effects on & Hernandez-Plata et al., 2015 [37]; de Souza et al., 2019 [38] \\
\hline $\begin{array}{l}\text { Rats, Endocrine } \\
\text { System }\end{array}$ & $\begin{array}{l}\text { Adverse effects on development \& } \\
\text { endocrine system }\end{array}$ & Pandey et al., 2015 [33]; Manservisi et al., 2019 [39] \\
\hline Rodent Behavior & Neurological effects on rodents & Cattani et al., 2017 [40] \\
\hline Rodent Reproduction & Reproductive toxicity & Owagboriaye et al., 2017 [31] \\
\hline $\begin{array}{l}\text { Rodent Pregnant } \\
\text { Female }\end{array}$ & Epigenetic transgenerational pathologies & Kubsad et al., 2019 [34]; Milesi et al., 2018 [41] \\
\hline $\begin{array}{l}\text { Rodent, Mammary } \\
\text { Gland }\end{array}$ & Alters development of mammary gland & Gomez et al., 2020 [42]; Zanardi et al., 2019 [43] \\
\hline $\begin{array}{l}\text { Rodent, Gut } \\
\text { Microbiome }\end{array}$ & $\begin{array}{l}\text { Increase of homosysteine; } \\
\text { risk of cardiovascular disease }\end{array}$ & Hu et al., 2020 [44] \\
\hline $\begin{array}{l}\text { Rat, Intestine \& Gut } \\
\text { Microbiome }\end{array}$ & $\begin{array}{l}\text { Induces inflammatory responses in small } \\
\text { intestine and alters gut microbiome }\end{array}$ & Tang et al. [45]; Chlopecka et al., 2016 [46] \\
\hline Mice oocytes & Induces damage in mice oocytes & Zhang et al., 2019 [47] \\
\hline Mice offspring & $\begin{array}{l}\text { Induces lipid metabolism Disruption in } \\
\text { offspring }\end{array}$ & Ren et al., 2019 [48] \\
\hline $\begin{array}{l}\text { Mice, perinatal } \\
\text { exposure }\end{array}$ & Decreased sperm; endocrine effects & Pham et al., 2019 [49] \\
\hline B. Soil & Impact on & Source Reporting Effects \\
\hline Soil health & Degraded & Silva et al., 2007 [50]; Van Bruggen et al., 2018 [51] \\
\hline Microbial population & $\begin{array}{l}\text { Reduced growth \& activity of soil biota } \\
\text { esp; N-fixing bacteria }\end{array}$ & $\begin{array}{l}\text { Zobiole et al., } 2010 \text { [52]; Meena et al. [53]; Santos \& Flores, } \\
1995 \text { [54] }\end{array}$ \\
\hline Earthworms & $\begin{array}{l}\text { Reduced tomato growth with no fruit; } \\
\text { increases soil acidity; diminishes } \\
\text { earthworm vitality }\end{array}$ & Owagboriaye et al., 2020 [55]; Garcia-Pérez et al., 2016 [56] \\
\hline Soil pseudomonas & Adverse effects on Pseudomonas species & Aristilde et al., 2017 [57] \\
\hline
\end{tabular}


Table 1. Cont.

\begin{tabular}{|c|c|c|}
\hline $\begin{array}{l}\text { C.Beneficial Insects \& } \\
\text { Non-Target Species }\end{array}$ & Effects & Studies Reporting Effects \\
\hline Bees & $\begin{array}{l}\text { Gut microbiota damaged; } \\
\text { Navigation disturbed; } \\
\text { Reproduction decline }\end{array}$ & $\begin{array}{l}\text { Balbuena et al., } 2014 \text { [58]; Vázquez et al., } 2018 \text { [59]; Vázquez } \\
\text { et al., } 2020 \text { [60]; Dai et al., 2018, [61]; Battisti et al., } 2021 \text { [62]; } \\
\text { Motta et al. [63]; Graffigna et al., } 2020 \text { [64]; }\end{array}$ \\
\hline Butterflies (Monarch) & Destruction of food supply & $\begin{array}{l}\text { Taylor, } 2020 \text { [65]; Pleasants, } 2017 \text { [66]; Crone et al., } 2019 \text { [67]; } \\
\text { Pleasants \& Oberhauser } 2013 \text { [68]; Flockhart et al., } 2015 \text { [69] }\end{array}$ \\
\hline Butterfly, C. Xanthus & $\begin{array}{l}\text { Deleterious effects on growth and } \\
\text { development }\end{array}$ & Ferreira-Junior et al., 2017 [70] \\
\hline Quails (Japanese) & Delayed plummage & Ruuskanen et al., 2019 [71] \\
\hline $\begin{array}{l}\text { Herbivores (feeding on } \\
\text { non-target crops) }\end{array}$ & Affects composition of microbiota & Gómez-Gallego et al., 2020 [72] \\
\hline Reptiles & Suppression of immune function & Siroski et al., 2016 [73] \\
\hline Frog (Amazonian) & Mutagenic and lethal effects & Ferrante et al., 2020 [74] \\
\hline Frog, embryos & Teratogenic effects and growth inhibition & Babalola et al., 2019 [75] \\
\hline D. Aquatic Species & Effects & Studies Reporting Effects \\
\hline Fish & $\begin{array}{l}\text { Impairs fish behavior, induces oxidative } \\
\text { stress on brain }\end{array}$ & Faria et al., 2020 [76] \\
\hline $\begin{array}{l}\text { Fish embryos } \\
\text { (Odontesthes } \\
\text { humensis embryos) }\end{array}$ & Morphological alterations & Zebral et al., 2017 [77] \\
\hline Crayfish & $\begin{array}{l}\text { Disruption of homeostasis Altering } \\
\text { biochemical \& Immunological function }\end{array}$ & Banaee et al., 2020 [78] \\
\hline Rainbow trout & Sublethal effects on liver cells & Santos et al., 2019 [79] \\
\hline Zebra fish & $\begin{array}{l}\text { Disrupted embryo development \& } \\
\text { energy metabolism; oxidative stress, } \\
\text { cardiovascular toxicity }\end{array}$ & $\begin{array}{l}\text { Lopes et al., } 2017 \text { [80]; Panetto et al., } 2019 \text { [81]; Roy et al., } \\
2016 \text { [82] }\end{array}$ \\
\hline Crab & $\begin{array}{l}\text { Imbalances in male reproductive function } \\
\text { Ovarian growth impairment }\end{array}$ & Canosa et al., 2014 [83]; Avigliano et al., 2018 [84] \\
\hline Salamander & $\begin{array}{l}\text { Affects natural behavior Exhibits } \\
\text { non-monotonic dose responses }\end{array}$ & Ghandi \& Cecala 2016 [85] \\
\hline Tadpoles & $\begin{array}{l}\text { Lethal effects; Sublethal effects affecting } \\
\text { Tadpole mobility }\end{array}$ & Herek et al., 2020 [86]; Agostini et al., 2020 [87] \\
\hline Picoplankton & $\begin{array}{l}\text { Structural changes in Picoplankton; } \\
\text { decrease in abundance }\end{array}$ & Sabio y Gracia et al., 2020 [88] \\
\hline
\end{tabular}

\section{Non-Tillage Agriculture and Weed Resistance}

Chemical herbicides have a special role in agriculture. They destroy weeds without destroying commercial crops. Pre-emergent herbicides prevent weeds from ever growing, while post-emergent herbicides destroy weeds that have already grown. Prior to herbicides, farmers used tillage practices, whereby they turn over the soil to destroy weeds whose roots have already been established. By turning over the soil there is a loss of rich topsoil which results in the pollution of surface waters and air. Tillage practices also involve fossil fuel use, contributing to atmospheric $\mathrm{CO}_{2}$.

Glyphosate-tolerant crops have contributed to the worldwide increase in agricultural herbicide applications. According to Powles (2008, 360): "In transgenic glyphosate-resistant crops (GRCs) glyphosate can be applied to the crop (post-emergence) to remove emerged weeds without crop damage. GRCs enable glyphosate to be used as an in-crop selective 
herbicide, providing easy, economical, efficient weed control along with other agronomic advantages such as earlier seeding and no-tillage" [89].

The non-tillage advantage is a key factor for sustainability since it protects soil quality. According to Powles (2008) [89]: “Tillage has been reduced where GR (glyphosate-resistant) crops have been adopted ... Utilization of tillage results in significant fossil fuel use with associated negative impacts." Both on the grounds of protecting soil from erosion and reducing atmospheric carbon, glyphosate has a positive sustainability effect on agriculture.

The benefits of glyphosate were reported by Duke (2020):

"the net influence of glyphosate on the environment has been generally positive when comparing its use with the weed management methods that it replaced... Adoption of GR (glyphosate-resistant) crops reduced tillage practices, increasing soil retention of carbon and decreasing the use of fossil fuels in agriculture". [90]

Kudsk and Mathiassen (2020) note: "Non-tillage/conservation agriculture is viewed as an effective strategy to prevent soil erosion and the loss of nutrients, which could become larger problems without glyphosate" [91].

The story would end here were it not for the development of weed resistance to the herbicide. Glyphosate-based herbicides were used for 20 years without observed cases of glyphosate-resistant weeds. Following the introduction of GMOs and glyphosate-tolerant crops, glyphosate-resistant weeds began to appear throughout the world. The first case of weeds exhibiting glyphosate resistance was discovered in 1998 [92]. By 2010, 10 weed species in the United States had been identified as glyphosate resistant, as well as 19 weed species globally. Alcántara-de la Cruz et al. reported 51 weed species resistant to herbicides in Brazil in 2020 [93].

Without the management of diversity in these agro-ecosystems, glyphosate-based herbicide use will not be sustainable. Such diversity includes the introduction of nonherbicide weed management along with herbicide use, as well as the varying of herbicides. By themselves, and at the rate at which they have been used, GBHs are not sustainable for agriculture because they will reach the end of their effectiveness through resistant weeds and thus must be met with a multiplicity of other methods of weed control.

Ravet et al. (2020) reports on glyphosate resistance occurring across North America [94] and Loddo et al. (2020) discuss glyphosate resistance growing in Europe [95]. Gaines et al. report on the glyphosate-resistant weed invasion in South America [96]. Powles (2008) ends his article with the following somewhat optimistic conclusion [89]: "Through avoiding intense glyphosate release and by maintenance of diversity, the longevity of the precious herbicide resource glyphosate and excellent GRC technologies can be sustained for future harvests and future generations." New research on glyphosate-based herbicides and sustainability continues to be carried out given the ubiquitous nature of these herbicides [97].

The simple transition from GBHs to non-till agriculture did not occur. According to Price et al. (2011), the introduction of transgenic seeds and glyphosate-resistant crops did not result in non-tillage farming. Rather it led to conservation: "Large-scale successful implementation of conservation tillage across the United States came only after the introduction of broad-spectrum herbicides for weed control ... Conservation tillage has numerous environmental benefits, including controlling soil erosion, which can be attributed to the accumulation of crop residues and the accumulation of crop residues and increased soil organic matter near the soil surface" [98]. The authors argue that with the rapid spread of glyphosate-resistant Palmer amaranth, commonly called pigweed, the efficacy of glyphosate is significantly compromised and with it the loss of conservation tillage.

In summary, GBHs by themselves cannot produce a non-tillage sustainable agricultural system, but to be successful must include other conservation methods and used with non-herbicide weed control practices. 


\section{Glyphosate and Soil Quality}

One of the core principles of sustainable agriculture is to protect the quality of the soil for future generations. Non-tillage or conservation tillage agriculture is supposed to do just that. However, it is important to consider the infusion of glyphosate-based herbicides including their adjuvants into the soil. Silva et al. (2007) have studied the distribution of glyphosate in agricultural top-soils in the European Union. Their study concluded [50]:

“... high levels of glyphosate and of its main metabolite AMPA (aminomethylphosphonic acid) have been often detected in agricultural soils across the EU. The presence of glyphosate and AMPA in agricultural soils may not only form a risk for soil health but also a potential risk of further spreading of these compounds across land, water, and air domains. Indeed, besides potential effects on local edaphic communities and on humans, that can be exposed to these substances by inhalation of contaminated dust particles, dermal contact, or ingestion of contaminated surface water, wind and water erosion have the potential to transport contaminants to all the environmental compartments: atmosphere, other soils, and surface waters. This information should be fully accounted for in reconsidering approval and use of GlyBH (glyphoosate-based herbicides). Additional efforts should be made to fully quantify the extent of soil contamination by glyphosate residues in agricultural soils worldwide, and to assess the related risk for humans and the environment."

Van Bruggen et al. (2018) report on the alteration of microbes in the soil from glyphosate applications. "Shifts in microbial compositions due to selective pressure by glyphosate may have contributed to the proliferation of plant and animal pathogens" [51]. In greenhouse tests, Zobiole et al. (2010), in relation to glyphosate-altered rhizosphere microorganisms, found: "Glyphosate applied to the GR soybean, regardless of cultivar, negatively impacts the complex interactions of microbial groups, biochemical activity, and root growth that can have subsequent detrimental effects on plant growth and productivity" [52]. Additional studies on the effect of GBHs on soil microbiota are listed in Table 1.

\section{GBHs, Milkweeds, and Monarch Butterflies}

Monarch butterflies are among nature's most beautiful living organisms. Their orange wings are covered with black lines and bordered with white dots. Monarchs are known for their seasonal migration, when they travel up to 4800 kilometers. They are pollinators of many types of wildflowers. Yet, these magnificent creatures are being decimated because their primary food source, milkweed, is destroyed by the massive spraying of herbicides across the landscape. Those who see the threat of extinction of Monarchs speak of the "milkweed limitation hypothesis." As reported by Taylor Jr. et al. (2020) [65]:

"The milkweed limitation hypothesis is supported by data showing that in the early 2000s the majority of Monarch production came from common milkweed, Asclepias syriaca, in corn and soybean fields in the Midwest ... . and that the abundance of those milkweeds declined precipitously due to glyphosate herbicide use in those fields ... The loss of the milkweeds from corn and soybean fields began in the late 1990s with the adoption of glyphosate-tolerant crops."

The studies of tagged Monarchs have corroborated the hypothesis that milkweed destruction is the cause of their decline. "Over the past decade and a half, milkweeds were virtually eliminated from agricultural fields." (Pleasants et al, 2016 [66]). An estimated $71 \%$ of the Monarch production potential of milkweeds on the Midwest landscape was eliminated, amounting to 25 million hectares of agricultural habitat that no longer had milkweeds. Crone et al. (2019) [67] reported that "increased use of glyphosate explains $77 \%$ of annual variation in Monarch abundance through time." Pleasants and Oberhauser (2013) [68] estimated that "there has been a 58\% decline in milkweeds on the Midwest landscape and an 81\% decline in Monarch production in the Midwest from 1999 to 2010." 
The evidence is very clear that the use of GBHs has reduced milkweed, which has largely contributed to the decline of Monarch butterflies [69].

\section{Glyphosate and Honeybees}

Honeybees are critical to crop pollination. Extensive spraying of glyphosate has damaged the gut microbiota of honeybees. Motta et al. found "that, exposure of bees to glyphosate can perturb their beneficial gut microbiota potentially affecting bee health and their effectiveness as pollinators" [99]. The authors state that for most bees the gut microbiota contains an enzyme targeted by glyphosate. Another study by Balbuena et al. (2014) [58] found that sublethal doses of glyphosate affects the honeybee's navigation. "In honeybees, exposure to the levels of GLY (glyphosate) commonly found in agricultural settings impairs the cognitive capacities needed to retrieve and integrate spatial information for a successful return to the hive ... honeybee navigation is affected by ingesting traces of the most widely used herbicide worldwide, with potential long-term negative consequences for colony forging success." Other studies and a meta-analysis support the conclusion that GBHs are toxic to honeybees [59-62]. GBH effects on other non-target species are given in Table 1.

\section{Effects on Aquatic Species}

When glyphosate enters surface waters it interacts with aquatic species. Zebral et al. (2017) [77] studied the effects of glyphosate-based herbicides on fish embryos. They concluded: "Roundup has the potential to produce morphological alterations in fish embryos even at the lower and ecologically relevant concentration tested $(0.36 \mathrm{mg}$ a.e. $/ \mathrm{L})$. This result corroborates the hypothesis that glyphosate alters the retinoic acid signaling pathway."

Studies of GBHs on other aquatic species report toxic effects on crayfish, Rainbow trout, Zebra fish, crabs, salamanders, tadpoles, frogs, and picoplankton. Additionally, by inducing oxidative stress on the brain, the herbicides impair fish behavior (see Table 1: D. Aquatic Species).

\section{Glyphosate Versus Glyphosate Formulations}

Many studies that have claimed to test glyphosate herbicides have not always distinguished pure glyphosate from herbicides containing glyphosate and other chemical compounds, referred to as glyphosate-based herbicide formulations. This created a confusion within the toxicology community since glyphosate was registered as the sole active ingredient, while the so-called inert ingredients or adjuvants (i.e., surfactants) were often proprietary and not disclosed. More than that, they were not tested independently. When researchers began studying the adjuvants, they learned that some of these compounds were more toxic than glyphosate [100].

Seralini and Jungers (2020) reported [101]: “We originally demonstrated the differential toxicity between glyphosate and its formulations marketed as Roundup ... we found that Roundup contained formulants that were 1000 times more toxic, and at a lower threshold more endocrine-disrupting than glyphosate." These results complicate the assessment of glyphosate's contribution to sustainable agriculture. Since the worldwide leader is Roundup, which consists of glyphosate and adjuvants (glyphosate formulation), most of the research on GBH toxicity has been carried out on Roundup or pure glyphosate, unless specifically stated.

Tóth et al. (2020) [102] studied thirteen glyphosate-based herbicides including Roundup and pure glyphosate, for their cytotoxic and hormonal effects. They concluded that "glyphosate is the least toxic compound in the glyphosate-based formulations. Co-formulants are not inert, between which synergistic effects could be greater than those with glyphosate." POE-15 (polyethoxylate-15, also a derivative POEA), a surfactant used in glyphosate formulations (GBHs), was banned in 2016 in the EU because of the toxicity of the adjuvant. GBHs are available in Europe with other co-formulants, which are listed as "inert compounds." Tóth et al. stated that in their study [102], "most of the investigated eleven free-marketed 
POE-15-free GBHs exhibited acute and chronic cytotoxicity and direct estrogenic and androgenic effects, while the pure active ingredient glyphosate acid proved to be ineffective in the applied biotests. Connection could not be found between the biological effects and the type or concentration of glyphosate salt; therefore, it can be concluded that toxicity and hormonal activity are linked to the formulation."

Tsui and Chu (2003) [103] have reported on the toxic effects of glyphosate, and the glyphosate-formulated products of Roundup and their most common co-formulant polyethoxylated tallow amine (POEA), on various model species selected from aquatic ecosystems, i.e., bacteria (Aliivibrio fischeri), microalgae (Selenastrum capricornutum, Skeletonema costatum), protozoa (Tetrahymena pyriformis, Euplotes vannus), and crustaceans (Ceriodaphnia dubia, Acartia tonsa). Based on the results, POEA was found to be the most toxic compound.

\section{Discussion}

The aim of this paper was to evaluate whether glyphosate-based herbicides (GBHs) are consistent with the goals and methods of sustainable agriculture. Since GBHs are but one part of an agricultural system, one can only offer evidence that this class of herbicides is consistent with the goals of sustainable agriculture, as discussed earlier in this paper, if they are not inconsistent with them. If GBHs violate enough criteria for sustainability, then the system in which they are part of cannot be considered sustainable. If GBHs are not found to be inconsistent with sustainable agriculture, it does not prove that the system as a whole is sustainable.

This method is reminiscent of Karl Popper's principle of falsifiability. Consider the hypothesis "All ravens are black." Finding a black raven does not prove that the hypothesis is true, although it is consistent with the hypothesis. However, finding a non-black raven falsifies the hypothesis. Falsification has more power than confirmation.

The hypothesis, "GBHs are consistent with sustainable agriculture," was evaluated by examining whether there was falsifying empirical evidence. The literature search revealed sufficient falsifying instances of the hypothesis (Table 1) that show this class of herbicides to be harmful to soil health, human and mammalian health, and biodiversity.

Figure 1 shows the number of articles indexed in Web of Science under the key words "glyphosate toxicology", of which there are almost 3000. The research into glyphosate begins to grow after 2005. Even without definitive direct human epidemiological studies demonstrating adverse health effects of GBHs, albeit there is sufficient circumstantial evidence of toxic human effects, the rodent and other animal studies provide an important proxy indicating that humans and the environment are at risk.

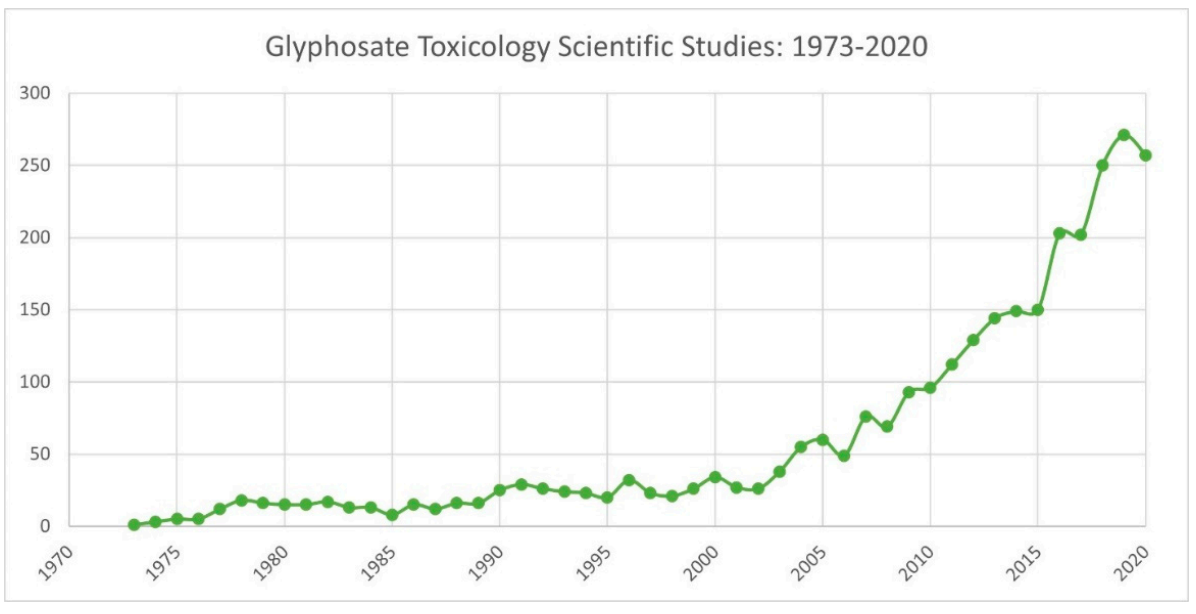

Figure 1. Glyphosate papers listed by year in Web of Science: 1973-2020. Legend: The total number of papers listed in Web of Science under the key word "glyphosate toxicology" over the span of 47 years is 2942. The smallest number is 1 (1973) and the largest is 271 (2019). 
This study has not undertaken a complete review of every scientific inquiry into each of the effects listed in Table 1. The sampling of research is not a weight-of-evidence evaluation for each parameter, which some may argue is necessary for a risk determination. With the exception of assuming that all of the studies that show unsustainable effects are false, given the number and range of human and animal studies with adverse effects, there is sufficient reason to conclude that GBHs do not meet the goals of sustainable agriculture.

One may argue that herbicides are necessary for modern agriculture, that GBHs are safer and more effective than others that have been approved, and that farming without glyphosate would be a challenge. This paper makes no claim about the comparative risks, benefits, or level of sustainability of GBHs compared to other herbicides. If one could not do without herbicides to feed the seven plus billion people on the planet, the question remains: are GBHs the closest we can get to sustainability? It may very well be that herbicide-driven agriculture, whatever the herbicide, is not consistent with sustainability goals. One of the claimed benefits of GBHs is their crop yield benefits. Wiese and Steinmann (2020) [104] report that previous studies have overestimated the benefits of glyphosate usage and that such studies were not relevant for specific farming conditions. The transition to sustainable agriculture and crop diversification is addressed in Locola et al. (2020), where monoculture and the role of GBHs are not considered inevitable [105].

In conclusion, whether or not GBHs are viewed as essential or unessential to contemporary agriculture, and notwithstanding their role in non-tillage agriculture, this study shows that glyphosate-based herbicides do not reach the bar of agricultural sustainability, with respect to humans and the environment, making the system they are part of unsustainable.

Funding: This research received no external funding

Conflicts of Interest: The author declares no conflict of interest.

\section{References}

1. Zeder, M.M. The origins of agriculture in the Near East. Curr. Anthropol. 2011, 52, S221-S235. [CrossRef]

2. Kuhlman, T.; Farrington, J. What is sustainability? Sustainability 2010, 2, 3436. [CrossRef]

3. Krimsky, S.; Wrubel, R. Agricultural Biotechnology and the Environment; University of Illinois: Urbana-Champaign, IL, USA, 1996.

4. FDA (U.S. Department of Health and Human Services-Food and Drug Administration). Statement of Policy: Foods Derived from New Plant Varieties. Fed. Regist. 1992, 57, 22984-23005.

5. Qaim, M. Role of new plant breeding technologies for food security and sustainable agricultural development. Appl. Econ. Perspect. Policy 2020, 42, 129-150. [CrossRef]

6. Wilson, A.K. Will gene-edited and other GM crops fail sustainable food systems? In Rethinking Food and Agriculture; Amir, K., Laila, K., Eds.; Woodhead Publishing Project: Duxford, UK, 2020; pp. 247-285. [CrossRef]

7. Owen, M.D.K. Current use of transgenic herbicide-resistant soybean and corn in the USA. Crop. Prot. 2000, 19, 765-771. [CrossRef]

8. World Commission on Environment and Development. Our Common Future; Oxford University Press: Oxford, UK, 1987.

9. Lichtfouse, E.; Navarrete, M.; Debaeke, P.; Souchère, V.; Alberola, C.; Ménassieu, J. Agronomy for sustainable agriculture: A review. Agron. Sustain. Dev. 2009, 29, 1-6. [CrossRef]

10. National Academies of Sciences, Engineering and Medicine. Toward Sustainable Agricultural Systems in the 21st Century; National Academies Press: Washington, DC, USA, 2010.

11. Buechs, W. Biotic indicators for biodiversity and sustainable agriculture: Introduction and background. Agric. Ecosyst. Environ. 2003, 98, 1-16. [CrossRef]

12. Krimsky, S. Glyphosate on Trial: The Search for Toxicological Truth. In The Fight Against Monsanto's Roundup: The Politics of Pesticides; Mitchel, C., Ed.; Skyhorse Press: New York, NY, USA.

13. Krimsky, S. Glyphosate Toxicology: What we can learn from the current controversy. In Environmental Exposures and Human Health Challenges; IGI Global Publishers: Hershey, PA, USA, 2019.

14. Perry, E.D.; Hennessy, D.A.; Moschini, G. Product concentration and usage: Behavioral effects in the glyphosate market. J. Econ. Behav. Organ. 2019, 158, 543-559. [CrossRef]

15. Benbrook, C.M. How did the U.S. EPA and IARC reach dramatically opposed conclusions on the genotoxicity of glyphosate-based herbicides? Environ. Sci. Eur. 2019, 31, 1-16. [CrossRef]

16. Donato, F.; Pira, E.; Ciocan, C.; Boffetta, P. Exposure to glyphosate and risk of non-Hodgkin lymphoma and multiple myeloma: An updated meta-analysis. La Med. Del Lav. 2020, 111, 63.

17. Williams, G.M.; Berry, C.; Burns, M.; Viana de Camargo, J.L.; Greim, H. Glyphosate rodent carcinogencity bioassay expert panel review. Crit. Rev. Toxicol. 2016, 46 Suppl. 1, 44-55. [CrossRef] [PubMed] 
18. Pu, Y.; Yang, J.; Chang, L.; Qu, Y.; Wang, S.; Zhang, K.; Xiong, Z.; Zhang, J.; Tan, Y.; Wang, X.; et al. Maternal glyphosate exposure causes autism-like behaviors in offspring through increased expression of soluble epoxide hydrolase. Proc. Natl. Acad. Sci. USA 2020, 117, 11753-11759. [CrossRef]

19. Cuhra, M.; Bohn, T.; Cuhra., P. Glyphosate: Too much of a good thing. Front. Environ. Sci. 2016, 4, 1-14. [CrossRef]

20. Myers, J.P.; Antoniou, M.; Blumberg, B.; Carroll, L.; Colborn, T.; Everett, L.G.; Hansen, M.; Landrigan, P.J.; Langphear, B.P.; Mesnage, P.; et al. Concerns over use of glyphosate-based herbicides and risks associated with exposures: A consensus statement. Environ. Health 2016, 15, 19-32. [CrossRef]

21. Muñoz, J.P.; Bleak, T.C.; Calaf, G.M. Glyphosate and the key characteristics of an endocrine disruptor: A review. Chemosphere 2020, 128619, 1-15. [CrossRef] [PubMed]

22. Zhang, L.; Rana, I.; Shaffer, R.M.; Taioli, E.; Sheppard, L. Exposure to glyphosate-based herbicides and risk for non-Hodgkin lymphoma: A meta-analysis and supporting evidence. Mutat. Res. 2019, 781, 186-206. [CrossRef] [PubMed]

23. Parvez, C.; Gerona, R.R.; Proctor, C.; Frieson, M.; Ashby, J.L.; Reiter, J.L.; Lui, Z.; Winchester, P.D. Glyphosate exposure in pregnancy and shortened gestational length: A prospective Indiana birth cohort study. Environ. Health 2018, 17, 23-35. [CrossRef]

24. Anifandis, G.; Amiridis, G.; Dafopoulos, K.; Daponte, A.; Dovolou, E.; Gavril, E.; Gorgogietas, V.; Kochpani, E.; Mamuris, Z.; Messihi, C.; et al. The in vitro impact of the herbicide Roundup on human sperm motility and sperm mitochondria. Toxics 2018, 6 , 2. [CrossRef] [PubMed]

25. Woźniak, E.; Siciŕiska, P.; Michalowicz., J. The mechanism of DNA change induced by Roundup 360 Plus, glyphosate and AMPA in human peripheral blood mononuclear cells-genotoxic risk assessment. Food Chem. Toxicol. 2018, 120, 510-522.

26. Hao, Y.; Zhang, Y.; Cheng, J.; Xu, W.; Xu, Z.; Gao, J.; Tao, L. Adjuvant contributes Roundup's unexpected effects on AS49 cells Adjuvant contributes Roundup's unexpected effects on AS49 cells. Environ. Res. 2020, 184, 109306. [CrossRef] [PubMed]

27. Hao, Y.; Chen, H.; Xu, W.; Gao, J.; Yang, Y.; Zhang, Y.; Tao, L. Roundup confers cytotoxicity through DNA damage and mitochondria-associated apoptosis induction. Environ. Pollut. 2019, 252 Pt A, 917-923. [CrossRef] [PubMed]

28. Defarge, N.; Takács, E.; Lozano, V.L.; Mesnage, R.; Spiroux de Vendômois, J.; Gilles-Eric Séralini, J.G.; Székács, A. Formulants in glyphosate-based herbicides disrupt aromatase activity in human cells below toxic levels. Int. J. Environ. Res. Public Health 2016, 13, 264. [CrossRef] [PubMed]

29. Agostini, L.P.; Dettogni, R.S.; Dos Reis, R.S.; Stur, E.; Dos Santos, E.V.W.; Ventorim, D.P.; Garcia, F.M.; Cardoso, R.C.; Graceli, J.B.; Louro, L.D. Effects of glyphosate exposure on human health: Insights from epidemiological and in vitro studies. Sci. Total Environ. 2020, 705, 1-16. [CrossRef]

30. Hurtado, D.; Velez-Torres, I. Toxic dispossession: On the social impacts of the aerial use of glyph osate on the sugarcane agroindustry in Columbia. Crit. Criminol. 2020, 28, 1-20. [CrossRef]

31. Owagboriaye, F.O.; Dedeke, G.A.; Ademolu, K.O.; Olujimi, O.O.; Ashidi, J.S.; Adeyinka, A.A. Reproductive toxicity of Roundup herbicide exposure in male albino rat. Exp. Toxicol. Pathol. 2017, 69, 461-468. [CrossRef]

32. Lozano, V.L.; Defarge, N.; Rocque, L.-M.; Mesnage, R.; Hennequin, D.; Cassier, R.; Spiroux de Vendômois, J.; Panoff, J.-M.; Séralini, G.-E.; Amiel, C. Sex dependent impact of Roundup on the rat gut microbiome. Toxicol. Rep. 2018, 5, 96-107. [CrossRef]

33. Pandey, A.; Rudraiah, M. Analysis of endocrine disruption effect of Roundup in adrenal gland of male rats. Toxicol. Rep. 2015, 2, 1075-1085. [CrossRef]

34. Kubsad, D.; Nilsson, E.E.; King, S.E.; Sadler-Riggleman, I.; Beck, D.; Skinner, M.K. Assessment of glyphosate induced epigenetic transgenerational inheritance of pathologies and sperm epimutations: Generational toxicology. Sci. Rep. 2019, 9, 6372-6389. [CrossRef] [PubMed]

35. Cai, W.; Ji, Y.; Song, X.; Guo, H.; Han, L.; Zhang, F.; Liu, X.; Zhang, H.; Zhu, B.; Xu, M. Effects of glyphosate exposure on sperm concentration in rodents: A systematic review and meta-analysis. Environ. Toxicol. Pharmacol. 2017, 55, 148-155. [CrossRef] [PubMed]

36. Schimpf, M.G.; Milesi, M.M.; Ingaramo, P.I.; Luque, E.H.; Varayoud, J. Neonatal exposure to a glyphosate-based herbicide alters the development of the rat uterus. Toxicology 2017, 376, 2-14. [CrossRef]

37. Hernandez-Plata, I.; Giordano, M.; Diaz-Muñoz, M.; Rodriguez, V.M. The herbicide glyphosate causes behavioral changes and alterations in dopaminergic markers in male Sprague-Dawley rat. NeuroToxicology 2015, 46, 79-91. [CrossRef] [PubMed]

38. de Souza, J.S.; Laureano-Melo, R.; Herai, R.H.; da Conceição, R.R.; Oliveira, K.C.; da Silva, I.D.C.G.; Dias-da-Silva, M.R.; Romano, R.M.; Romano, M.A.; Maciel, R.M.B.; et al. Material glyphosate-based herbicide exposure affects antioxidant-related genes in the brain and serum metabolites of male rat offspring. NeuroToxicology 2019, 74, 121-131. [CrossRef] [PubMed]

39. Manservisi, F.; Lesseur, C.; Panzacchi, S.; Mandriole, D.; Falcioni, L.; Bua, L.; Manservigi, M.; Spinaci, M.; Galeati, G.; Montovani, A.; et al. The Ramazzini Institute 13-week pilot study glyphosate-based herbicides administered at human equivalent dose to Sprague Dawley rats: Effects on development and endocrine system. Environ. Health 2019, 18, 15-31. [CrossRef]

40. Cattani, D.; Cesconetto, P.A.; Tavares, M.K.; Parisotto, E.B.; De Oliveira, P.A.; Rieg, C.E.H.; Leite, M.C.; Prediger, R.D.S.; Wendt, N.C.; Razerra, G.; et al. Developmental exposure to glyphosate-based herbicide and depressive-like behavior in adult offspring: Implication of glutamate excitotoxicity and oxidative stress. Toxicology 2017, 387, 67-80. [CrossRef]

41. Milesi, M.M.; Lorenz, V.; Beldomenico, P.M.; Vaira, S.; Varayoud, J.; Luque, E.H. Prenatal exposure to glyphosate-based herbicide on female rat reproductive outcomes and induces second generation adverse effects in Wistar rats. Arch. Toxicol. 2018, 92, 2629-2643. [CrossRef] 
42. Gomez, A.L.; Altamirano, G.A.; Tschopp, M.V.; Bosquiazzo, V.L.; Muñoz-de-Toro, M.; Kass, L. Exposure to glyphosate-based herbicide alters the expression of key regulators of mammary gland development on pre-pubertal male rats. Toxicology 2020, 439, 152377-152487. [CrossRef]

43. Zanardi, M.V.; Schimpf, M.G.; Gastiazoro, M.P.; Milesi, M.M.; Muñoz-de-Toro, M.; Varayoud, J.; Durando, M. Glyphosate-based herbicide induces hyperplastic ducts in the mammary gland of aging Wistar rats. Molecular \& Cellular. Endocrinology 2019, 501, 110658 .

44. Hu, J.; Lesseur, C.; Yu, M.; Manservisi, F.; Panzacchi, S.; Mandrioli, D.; Belpoggi, F.; Chen, J.; Petrick, L. Disruption of urine metabiome and its interaction with gut microbiome by low-dose exposure of glyphosate-based herbicide in a rodent model. Sci. Rep. 2021, 11, 3265.

45. Tang, Q.; Tang, J.; Ren, X.; Li, C. Glyphosate exposure induces inflammatory responses to the small intestine and alters gut microbial composition in rats. Environ. Pollut. 2020, 261, 114129. [CrossRef]

46. Chlopecka, M.; Mendel, M.; Dziekan, N.; Karlik, W. The effect of glyphosate-based herbicide Roundup and its co-formulant POEA on the motoric activity of the rat intestine, in-vitro study. Environ. Toxicol. Pharmacol. 2017, 49, 156-162. [CrossRef]

47. Zhang, J.W.; Xu, D.Q.; Fang, X.Z. The toxic effects and possible mechanisms of glyphosate on mouse oocytes. Chemosphere 2019, 237, 124435. [CrossRef] [PubMed]

48. Ren, X.; Dai, P.; Perveen, A.; Tang, Q.; Zhao, L.; Jia, X.; Li, Y.; Li, C. Effects of chronic exposure to pregnant mice on hepatic lipid metabolism in offspring. Environ. Pollut. 2019, 254, 112906. [CrossRef] [PubMed]

49. Pham, T.H.; Derian, L.; Kervarrec, C.; Kernanec, P.-Y.; Jégou, B.; Smagyulova, F.; Gely-Pernot, A. Perinatal exposure to glyphosate and glyphosate-based herbicide affect spermatogenesis in mice. Toxicol. Sci. 2019, 169, 260-271. [CrossRef]

50. Silva, V.; Montanarella, L.; Jones, A.; Fernández-Ugalde, O.; Mol, H.G.J.; Coen, J.R.; Geissen, V. Distribution of glyphosate and aminomethylphosphonic acid (AMPA) in agricultural topsoils of the European Union. Sci. Total Environ. 2019, 621, 1259-1352. [CrossRef]

51. Van Bruggen, A.H.C.; He, M.M.; Shin, K.; Mai, V.; Jeong, K.C.; Finckh, M.R.; Morris, J.G., Jr. Review: Environmental and health effects of the herbicide glyphosate. Sci. Total Environ. 2018, 616, 255-268. [CrossRef] [PubMed]

52. Zobiole, L.H.S.; Kremer, R.J.; Oliveira, R.S., Jr.; Constantin, J. Glyphosate affects micro-organisms in rhizospheres of glyphosateresistant soybeans J. Appl. Microbiol. 2010, 110, 118-127. [CrossRef] [PubMed]

53. Meena, R.S.; Kumar, S.; Datta, R.; Lai, R.; Vijayakumar, V.; Brtnicky, M.; Sharma, M.P.; Yadav, G.S.; Jhariya, M.K.; Jangir, C.K.; et al. Impact of agrochemicals on soil microbiota and management: A review. Land 2020, 9, 34. [CrossRef]

54. Santos, A.; Flores, M. Effects of glyphosate on nitrogen fixation of free-living heterotrophic bacteria. Lett. Appl. Microbiol. 1995, 20, 349-352. [CrossRef]

55. Owagboriaye, F.; Dedeke, G.; Bamidele, J.; Bankole, A.; Aladesida, A.; Feyisola, R.; Adelke, M.; Adekunie, O. Wormcasts produced by three earthworm species (Alma millsoni, cudrilus eugeniae and Libyodrilus violaceus) exposed to glyphosate-based herbicide reduce growth, fruit yield and quality of tomato (Lycopersicon esculentum). Chemosphere 2020, 250, 126270. [CrossRef]

56. Garcia-Pérez, J.A.; Alarcón, E.; Hernández, Y.; Hernández, C. Impact of litter contaminated with glyphosate-based herbicide on the performance of Pontoscolex corethrurus, soil phosphatase activities and soil pH. Appl. Soil Ecol. 2016, 104, 31-41.

57. Aristilde, L.; Reed, M.L.; Wilkes, R.A.; Youngster, T.; Kukurugya, M.A.; Katz, V.; Sasaki, C.R.S. Glyphosate-induced specific and widespread perturbations in the metabolome of soil pseudomonas species. Front. Environ. Sci. 2017, 5, 34. [CrossRef]

58. Balbuena, M.S.; Tison, L.; Hahn, M.-L.; Greggers, U.; Menzel, R.; Farina, W.M. Effects of sublethal doses of glyphosate on honeybee navigation. J. Exp. Biol. 2015, 218, 2799-2805. [CrossRef] [PubMed]

59. Vázquez, D.E.; Ilina, N.; Pagano, E.A.; Zavala, J.A.; Farina, W.M. Glyphosate affects the larval development of honeybees depending on the susceptibility of colonies. PLOS ONE 2018. [CrossRef]

60. Vázquez, D.E.; Balbuena, M.S.; Chaves, F.; Gora, J.; Menzel, R.; Farina, W. Sleep in honeybees is affected by the herbicide glyphosate. Sci. Rep. 2020, 10, 10516.

61. Dai, P.; Yan, Z.; Ma, S.; Yang, Y.; Wang, Q.; Hou, C.; Wu, Y.; Liu, Y.; Diao, Q. The herbicide glyphosate negatively affects midgut bacterial communities and survival of honeybee during larvae reared in vitro. J. Agric. Food Chem. 2018, 66, 7786-7793. [CrossRef] [PubMed]

62. Battisti, L.; Potrich, M.; Sampaio, A.R.; de Castilhos Ghisi, N.; Costa-Maia, F.M.; Abati, R.; dos Reis Martinez, C.B.; Sofia, S.H. Is glyphosate toxic to bees? A meta-analytical review. Sci. Total Environ. 2021, 767, 145397. [CrossRef]

63. Motta, E.V.S.; Mak, M.; De Jong, T.K.; Powell, J.E.; O’Donnell, A.; Suhr, K.J.; Riddington, I.M.; Moran, N.A. Oral and topical exposure to glyphosate in herbicide formulation impact the gut microbiota and survival rates of honeybees. Appl. Environ. Microbiol. 2020, 86, 1-21. [CrossRef]

64. Graffigna, S.; Marrero, H.J.; Torretta, J.P. Glyphosate commercial formulation negatively affects the reproductive success of solitary wild bees in a Pampean agroecosystem. Apidologie 2020, 1-10. [CrossRef]

65. Taylor, O.R., Jr.; Pleasants, J.M.; Grundel, R.; Pecoraro, S.D.; Lovett, J.P.; Ryan, A. Evaluating the migration mortality hypothesis using Monarch tagging data. Front. Ecol. Evol. 2020, 8, 1-13. [CrossRef]

66. Pleasants, J.M.; Williams, E.H.; Brower, L.P.; Oberhauser, K.S.; Taylor, O.R. Conclusion of no decline in summer Monarch population not supported. Ann. Entomol. Soc. Am. 2016, 109, 169-171. [CrossRef]

67. Crone, E.E.; Pelton, E.M.; Brown, L.M.; Thomas, C.C.; Schultz, C.B. Why are monarch butterflies declining in the West? Understanding the importance of multiple correlated drivers. Ecol. Appl. 2019, 29, 1-13. [CrossRef] [PubMed] 
68. Pleasants, J.M.; Oberhauser, K.S. Milkweed loss in agricultural fields because of herbicide use: Effect on the monarch butterfly population. Insect Conserv. Divers. 2013, 6, 135-144. [CrossRef]

69. Flockhart, D.T.T.; Pichancourt, J.-B.; Norris, D.R.; Martin, T.G. Unravelling the annual cycle in a migratory animal breeding-season habitat loss drives population declines of monarch butterflies. J. Anim. Ecol. 2015, 84, 155-165. [CrossRef]

70. Ferreira-Junior, D.F.; Sarmento, R.A.; de Souza Saraiva, A.; Pereira, R.R.; Picanco, M.C.; Pestana, J.L.T.; Soares, A.M.V.M. Low concentrations of glyphosate-based herbicide affect the development of Chironomus xanthus. Waterair Soil Pollut. 2017, $228,390$. [CrossRef]

71. Ruuskanen, S.; Rainio, M.J.; Kuosmanen, V.; Laihonen, M.; Saikkonen, K.; Saloniemi, I.; Helander, M. Female preference and adverse development effects of glyphosate-based herbicide on ecologically relevant traits in Japanese quails. Environ. Sci. Technol. 2019, 54, 1128-1135. [CrossRef]

72. Gómez-Gallego, C.; Raino, M.J.; Collado, M.C.; Montziari, A.; Salminen, S.; Saikkonen, K.; Helander, M. Glyphosate-based herbicide affects the composition of microbes associated with Colorado potato beetle (Leptinotarsa decemlineata). FEMS Microbiol. Lett. 2020, 367, 1-9.

73. Siroski, P.A.; Poletta, G.L.; Latorre, M.A.; Merchant, M.E.; Ortega, H.H.; Mudry, M.D. Immunotoxicity of commercial-mixed glyphosate in broad snouted caiman (Caiman latirostris). Chem. -Biol. Interact. 2016, 244, 64-70. [CrossRef] [PubMed]

74. Ferrante, L.; Fearnside, P.M. Evidence of mutagenic and lethal effects of herbicides on Amazonian frogs. Acta Amaz. 2020, 50, 363-366. [CrossRef]

75. Babalola, O.O.; Truter, J.C.; van Wyk, J.H. Mortality, teratogenicity and growth inhibition of three glyphosate formulants using frog embryo teratogenesis assay-Xenopus. J. Appl. Toxicol. 2019, 39, 1257-1266. [CrossRef]

76. Faria, M.; Bedrossiantz, J.; Ramírez, J.R.R.; Mayol, M.; García, G.H.; Bellot, M.; Prats, E.; Garcia-Reyero, N.; Gómez-Canela, C.; Gómez-Oliván, L.M.; et al. Glyphosate targets fish monoaminergic systems leading to oxidative stress and anxiety. Environ. Int. 2020, 146, 106253. [CrossRef] [PubMed]

77. Zebral, Y.D.; Costa, P.G.; de Castro Knopp, B.; Lansini, L.R.; Zafalon-Silva, B.; Biancini, A.; Robaldo, R.B. Effects of a glyphosatebased herbicide in pejerrey Odontesthes humensis embryonic development. Chemosphere 2017, 185, 860-867. [CrossRef]

78. Banaee, M.; Akhlaghi, M.; Soltanian, S.; Sureda, A.; Gholamhosseini, A.; Rakhshaninejad, M. Combined effects of exposure to sub-lethal concentration of the insecticide chlorpyrifos and the herbicide glyphosate on the biochemical changes in the freshwater crayfish Pontastacus leptodactylus. Ecotoxicology 2020, 29, 1500-1515. [CrossRef]

79. Santos, S.W.; Gonzalez, P.; Cormier, B.; Mazzella, N.; Bonnaud, B.; Morin, S.N.C.; Costa, E.P.d.C.; Marin, B.; Cachot, J. A glyphosate-based herbicide induces sub- lethal effects in early life stages and liver cell line of rainbow trout, Oncorhynchus mykiss. Toxicology 2019, 216, 105291. [CrossRef] [PubMed]

80. Lopes, F.M.; Caldas, S.S.; Primel, E.G.; da Rosa, C.E. Glyphosate adversely affects Danio rerio males: Acetylcholinesterase modulation and oxidative stress. Zebrafish 2017, 14, 97-105. [CrossRef] [PubMed]

81. Panetto, O.S.; Gomes, H.F.; Gomes, D.S.F.; Campos, E.; Romeiro, N.C.; Costa, E.P.; do Carmo, P.R.L.; Feitosa, N.M.; Moraes, J. The effects of Roundup in embryo development and energy metabolism in the zebrafish (Danio rerio). Comp. Biochem. Physiol. Part. C Toxicol. Pharmacol. 2019, 222, 74-81. [CrossRef]

82. Roy, N.M.; Ochs, J.; Zambrzycka, E.; Anderson, A. Glyphosate induces cardiovascular toxicity in Danio reno. Environ. Toxicol. Pharmacol. 2016, 46, 292-300. [CrossRef] [PubMed]

83. Canosa, I.S.; Zanitti, M.; Lonné, N.; Medesani, D.A. Imbalances in the male reproductive function of the estuarine crab Neohelice granulata, caused by glyphosate. Ecotoxicol. Environ. Saf. 2019, 30, 1-7. [CrossRef]

84. Avigliano, L.; Alvarez, N.; MacLoughlin, C.; Rodriguez, E.M. Effects of glyphosate on egg incubation, larvae hatching, and ovarian rematuration in the estuarine crab Neohelice granulata. Environ. Toxicol. Chem. 2014, 8, 1879-1884. [CrossRef] [PubMed]

85. Ghandi, J.S.; Cecala, K.K. Interactive effects of temperature and glyphosate on the behavior of blue ridge two-lined salamanders, Eurycea wilderae. Environ. Toxicol. Chem. 2016, 35, 2297-2303.

86. Herek, J.S.; Vargas, L.; Trindade, S.A.R.; Rutkoski, C.F.; Macagnan, N.; Hartman, D.A.; Hartman, M.T. Can environmental concentrations of glyphosate affect survival and cause malformation in amphibians? Effects from a glyphosate-based herbicide on Physalaemus cuvieri and P. gracilis (Anura: Leptodactylidae). Environ. Sci. Pollut. Res. 2020, 27, 22619-22630. [CrossRef]

87. Agostini, M.G.; Roesler, I.; Bonetto, C.; Ronco, A.E.; Bilenca, D. Pesticides in the real world: The consequences of GMO-based intensive agriculture on native amphibians. Biol. Conserv. 2020, 241, 108355. [CrossRef]

88. Sabio y Garcia, C.A.; Schiaffino, M.R.; Lozano, V.L.; Vera, M.S.; Ferraro, M.; Izaguirre, I.; Pizarro, H. New findings on the effect of glyphosate on autotrophic and heterotrophic picoplankton structure: A microcosm approach. Aquat. Toxicol. 2020, $222,105463$. [CrossRef] [PubMed]

89. Powles, S.B. Evolved glyphosate-resistant weeds around the world: Lessons to be learnt. Pest. Manag. Sci. 2008, 64, 360-365. [CrossRef] [PubMed]

90. Duke, S.O. Glyphosate: Environmental fate and impact. Weed Sci. 2020, 68, 201-207.

91. Kudsk, P.; Mathiassen, S.K. Pesticide regulation in the European Union and the glyphosate controversy. Weed Sci. 2020, 68, 214-222. [CrossRef]

92. Wechsler, S.; McFaddersand, J.; Smith, D. A structural model of herbicide demand and glyphosate resistance on U.S. cornfields In Proceedings of the Agricultural \& Applied Economics Association. No. 235998. Annual Meeting, Boston, MA, USA, 31 July-2 August 2016; 2016. 
93. Alcántara, R.; de Oliveira, G.M.; Carvalho, L.B. Herbicide resistance in Brazil: Status, impacts, and future challenges. In Herbicides-Current Research and Case Studies in Use.; Price, A., Kelton, J., Eds.; IntechOpen: London, UK, 2020.

94. Ravet, K.; Sparks, C.; Dixon, A.; Küpper, A.; Westra, E.; Pettinga, D.; Tranel, P.; Felix, J.; Morishita, D.; Jha, P.; et al. Genomic-based epidemiology reveals gene flow and independent origins of glyphosate resistance in Bassiria scoparia populations across North America; Authorea preprints; Atypon: Santa Clara, CA, USA, 2020.

95. Loddo, D.; Imperatore, G.; Milani, A.; Panozzo, S.; Farinati, S.; Sattin, M.; Zanin, G. First report of glyphosate-resistant biotype of Eleusine Indica (L.) Gaertn in Europe. Agronomy 2020, 1692. [CrossRef]

96. Gaines, T.; Slavov, G.; Hughes, D.; Kuepper, A.; Sparks, C.; Oliva, J.; Vila-Aiub, M.; Garcia, M.; Merotto, A., Jr.; Neve, P. Investigating the origins and evolution of a glyphosate-resistant weed invasion in South America. Authorea Prepr. 2020. [CrossRef]

97. Owen, M.; Dixon, P.; Shaw, D.; Weller, S.C.; Young, B.G.; Wilson, R.G.; Jordan, D.L. Sustainability of glyphosate-based weed management: The Benchmark study. Iowa State University Digital Repository. 2010. Available online: https://lib.dr.iastate.edu/ cgi/viewcontent.cgi?article=1045\&context=stat_las_pubs (accessed on 10 February 2021).

98. Price, A.J.; Balkcom, K.S.; Culpepper, S.A.; Kelton, J.A.; Nichols, R.L.; Schomberg, H. Glyphosate-resistant Palmer amaranth: A threat to conservation tillage. J. Soil Water Conserv. 2011, 66, 265-275. [CrossRef]

99. Motta, E.V.S.; Raymann, K.; Moran, N.A. Glyphosate perturbs the gut microbiota of honeybees. PNAS 2018, 115, 10305-10310. [CrossRef]

100. Mesnage, R.; Benbrook, C.; Antoniou, M.N. Insight into the confusion over surfactant co-formulants in glyphosate-based herbicides. Food Chem. Toxicol. 2019, 128, 137-145. [CrossRef]

101. Séralini, G.-E.; Jungers, G. Toxic compounds in herbicides without glyphosate. Food Chem. Toxicol. 2020, 146, 1-7. [CrossRef] [PubMed]

102. Tóth, G.; Háhn, J.; Radó, J. Cytotoxicity and hormonal activity of glyphosate-based herbicides. Environ. Pollut. 2020, $265,115027$.

103. Tsui, M.T.K.; Chu, L.M. Aquatic toxicity of glyphosate-based formulations: Comparison between different organisms and the effects of environmental factors. Chemosphere 2003, 52, 1189-1197. [CrossRef]

104. Weise, A.; Steinmann, H.-H. Yield effects associated with glyphosate use in non-GMO arable farming: A review. Crop. Prot. 2020, 134, 105148. [CrossRef]

105. Iocola, I.; Angevin, F.; Bockstaller, C.; Catarino, R.; Curran, M.; Messéan, A.; Schader, C.; Stilmant, D.; van Stappen, F.; Vanhove, P.; et al. An actor-oriented multi-criteria assessment framework to support a transition towards, sustainable agricultural systems based on crop diversification. Sustainability 2020, 12, 5434. [CrossRef] 